\title{
Review of Privacy and Confidentiality Issues: A Guide for Libraries and Their Lawyers
}

Diane Kolosionek

Cleveland State University, d.kolosionek44@csuohio.edu

Follow this and additional works at: https://engagedscholarship.csuohio.edu/msl_facpub

Part of the Library and Information Science Commons

How does access to this work benefit you? Let us know!

Publisher's Statement

(c) 2009 Taylor \& Francis (Routledge)

\section{Original Citation}

Kolosionek, Diane. (2009). Review of Privacy and Confidentiality Issues: A Guide for Libraries and Their Lawyers. Collection Management, 34(4), 308-310.

\section{Repository Citation}

Kolosionek, Diane, "Review of Privacy and Confidentiality Issues: A Guide for Libraries and Their Lawyers" (2009). Michael Schwartz Library Publications. 52.

https://engagedscholarship.csuohio.edu/msl_facpub/52

This Book Review is brought to you for free and open access by the Michael Schwartz Library at EngagedScholarship@CSU. It has been accepted for inclusion in Michael Schwartz Library Publications by an authorized administrator of EngagedScholarship@CSU. For more information, please contact library.es@csuohio.edu. 


\section{Cleveland State University EngagedScholarship@CSU}

$1-1-2009$

\section{Privacy and Confidentiality Issues: A Guide for Libraries and Their Lawyers}

Diane Kolosionek

\section{Repository Citation}

Kolosionek, Diane, "Privacy and Confidentiality Issues: A Guide for Libraries and Their Lawyers" (2009). Library Faculty Publications. Paper 1. http://engagedscholarship.csuohio.edu/msl_facpub/1 
Diane Kolosionek

\section{PRIVACY AND CONFIDENTIALITY ISSUES: A GUIDE FOR LIBRARIES AND THEIR LAWYERS}

This article was originally published in:

Kolosionek, Diane. (2009). Review of Privacy and Confidentiality Issues: A Guide for Libraries and Their Lawyers. Collection Management, 34(4), 308-310.

Post-print prepared by MSL Academic Endeavors, the imprint of the Michael Schwartz Library at Cleveland State University (2012)

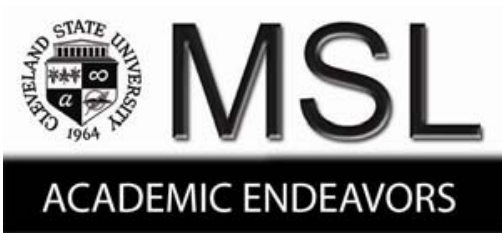


PRIVACY AND CONFIDENTIALITY ISSUES: A GUIDE FOR LIBRARIES AND THEIR LAWYERS. Theresa Chmara. Chicago, IL: American Library Association, 2009, 98 pp., ISBN 978-0-8389-0970-6, soft cover, \$40.00.

Privacy and Confidentiality Issues is a very useful resource that addresses privacy and confidentiality concerns in libraries, which have become even more important and complex due to the expansion of the federal government's authority to access private information after September 11th. The author, Theresa Chmara, is an attorney with extensive litigation experience in matters involving First Amendment issues. In this book, Chmara offers practical advice and guidance to library directors, managers, attorneys, and staff for handling requests for patron circulation and Internet use records. She presents the contents of this book in a clear manner without confusing legal jargon, which makes it easy for the layperson to understand.

The book comprises seven chapters where information is organized in a FrequentlyAsked-Questions (FAQ) format. In addition, court case studies that highlight privacy and confidentiality issues are included in several of the chapters. The chapters cover the types of privacy and confidentiality issues that arise in libraries: First Amendment rights, privacy and confidentiality issues related to the Internet, applicable state statutes, minors’ First Amendment and privacy rights, relevant federal laws, and the development of library privacy policies. Although this book is less than 100 pages long, it is filled with much valuable information.

The first chapter is an introduction to First Amendment rights that apply in library settings and how these rights can be challenged when libraries receive requests for patron records, such as subpoena requests from law enforcement officials conducting criminal investigations. In libraries, patrons typically exercise their First Amendment right to receive information, either with or without the assistance of library staff. In chapter 2, the author discusses the need for privacy policies in libraries, the types of privacy policies libraries should 
adopt, and the responses libraries can provide when requested to produce patron information that is protected by a privacy policy. A library's policy should cover patron borrowing records for materials in all formats, not just books, as well as patron records concerning Internet use. This chapter reviews the types of requests for patron information that libraries might receive and the appropriate responses to each request that can protect the First Amendment rights of patrons. The six types of requests discussed are: (1) informal request for information; (2) Open Records Act request; (3) subpoena request; (4) search warrant demand; (5) Patriot Act request; and (6) National Security Letter request. Last, chapter 2 summarizes legal tests that courts have applied when balancing First Amendment interests with the interests of the requesters.

Chapter 3 examines privacy and confidentiality issues related to the Internet. It includes a discussion of patrons' Internet use records, as well as the use of computer privacy screens and Internet filters to protect libraries from hostile work environment claims. It also reviews the types of unprotected or illegal speech that can be accessed via the Internet. Chapter 4 provides a general overview of state privacy and confidentiality statutes as they pertain to library records. More detailed state information can be found in the book's appendix. Chapter 5 considers minors' First Amendment rights and rights to privacy. Chapter 6 covers federal laws that impact library privacy and confidentiality. Here readers can learn about library record requests issued under the U.S. Patriot Act or by National Security Letters. In chapter 7, crucial questions regarding developing library privacy policies are answered.

The book contains one appendix, which is a summary compiled in September 2008 of state privacy and confidentiality statutes related to library patron records. Since state laws can change at any time, the appendix serves only as a starting point for further legal research. The author cautions readers that further research will be required to determine if the laws are still in 
effect and to determine if any changes were made to any parts of these laws when a library must prepare a response to an actual request.

I highly recommend this book, and I learned much from it. The book is essential reading for public and academic library directors and managers. It also would be beneficial reading for librarians and library staff who want to gain more knowledge about privacy and confidentiality issues in order to protect their patrons' rights. It is a great source for library personnel and their attorneys to consult when responding to privacy and confidentiality challenges.

Diane Kolosionek Education and Urban Affairs Librarian Cleveland State University Library Cleveland, Ohio 